\title{
TWO YEARS OF BED PROCUREMENT FOR PATIENTS WITH SPINAL CORD LESIONS ${ }^{1}$
}

\section{A Report on Progress and Experiences at the Bed Procurement Service at the Industrial Injuries Insurance Institute for Research in Traumatology at Frankfurt/Main}

\author{
By F.-W. Meinecke, M.D. \\ Industrial Injuries Insurance Institute for Research in Traumatology, \\ Frankfurt/Main, West Germany
}

In cooperation with: M. AALAM/Karlsbad-Langensteinbach, H. Bilow/Tübingen, U. BöTel/Bochum, G. BötTCHer/Hamburg, H. J. Drossel/Berlin, J. Gerner/Bad WildungenReinhardshausen, W. GRÜNINGER/Bayreuth, M. HADDENBROCK/Ludwigshafen, E. LAMBIRIS/ Berlin, H. D. Lang/Koblenz, K.-L. Lemberg/Bayreuth, H. MitTelmeIER/HomburgSaar, V. Paeslack/Heidelberg, M. H. RuIdisch/Murnau, D. Stock/Frankfurt am Main,

K. L. Turban/Duisburg, A. WItZENRATH/Hessisch Lichtenau

Key words: Recent spinal cord lesions; Special centres; Comprehensive treatment; Bed procurement; Planning programmes.

TRYING to summarise Sir Ludwig Guttmann's fundamental life-work in one sentence one could say as follows: the comprehensive rehabilitation of sufferers from spinal cord impairment from the very beginning up to the end of the whole treatment will lead to the best results in spinal units. This statement has been confirmed as correct by the experiences of numerous authors all over the world (e.g. in German Arens, Bürkle de la Camp, Bundesärtztekammer, Guttmann, Leimbach, Lemberg, Meinecke 1970, Paeslack 1968, 1971, 1977, Probst). In consequence, there is no question that every sufferer from a spinal cord lesion should be transferred to a spinal unit as early as possible, regardless of the origin of the paralysis or to which insurance the patient may belong. There is no doubt that this cannot be realised in most countries. In the specialised centres there is only an insufficient number of beds available

The situation in the Federal Republic of Germany has been described in English in detail previously (Meinecke, I964, 1967, I969; Stoephasius). Within the last 20 years the situation has very much improved and the Industrial Injuries Insurance Institutes have been of leading importance in this respect. In 1978 they published a second edition of a memorandum: 'About the reorganisation of spinal centres in the Federal Republic of Germany with guidelines for reconstructions' (Hauptverband der Gewerblichen Berufsgenossenschaften). Here they demanded centres of 60,80 or Ioo beds each, which should be distributed all over the country in order to provide special care as near as possible to the patient's native place.

${ }^{1}$ Dedicated to Sir Ludwig Guttmann's 8oth birthday. 
A look at the map (Fig. I) shows clearly that these conditions are not fulfilled, neither with regard to the size of the centres nor geographically. Only five centres are in accordance with the above mentioned memorandum.

A physician responsible for the primary care of such a patient and willing to transfer him to a spinal unit had to ring up all the different centres. That was timeconsuming, unsuccessful in many cases, and often he was not familiar with the addresses of the mostly overcrowded centres. The result caused many disadvantages for the patients, the physicians and the mostly overcrowded hospitals.

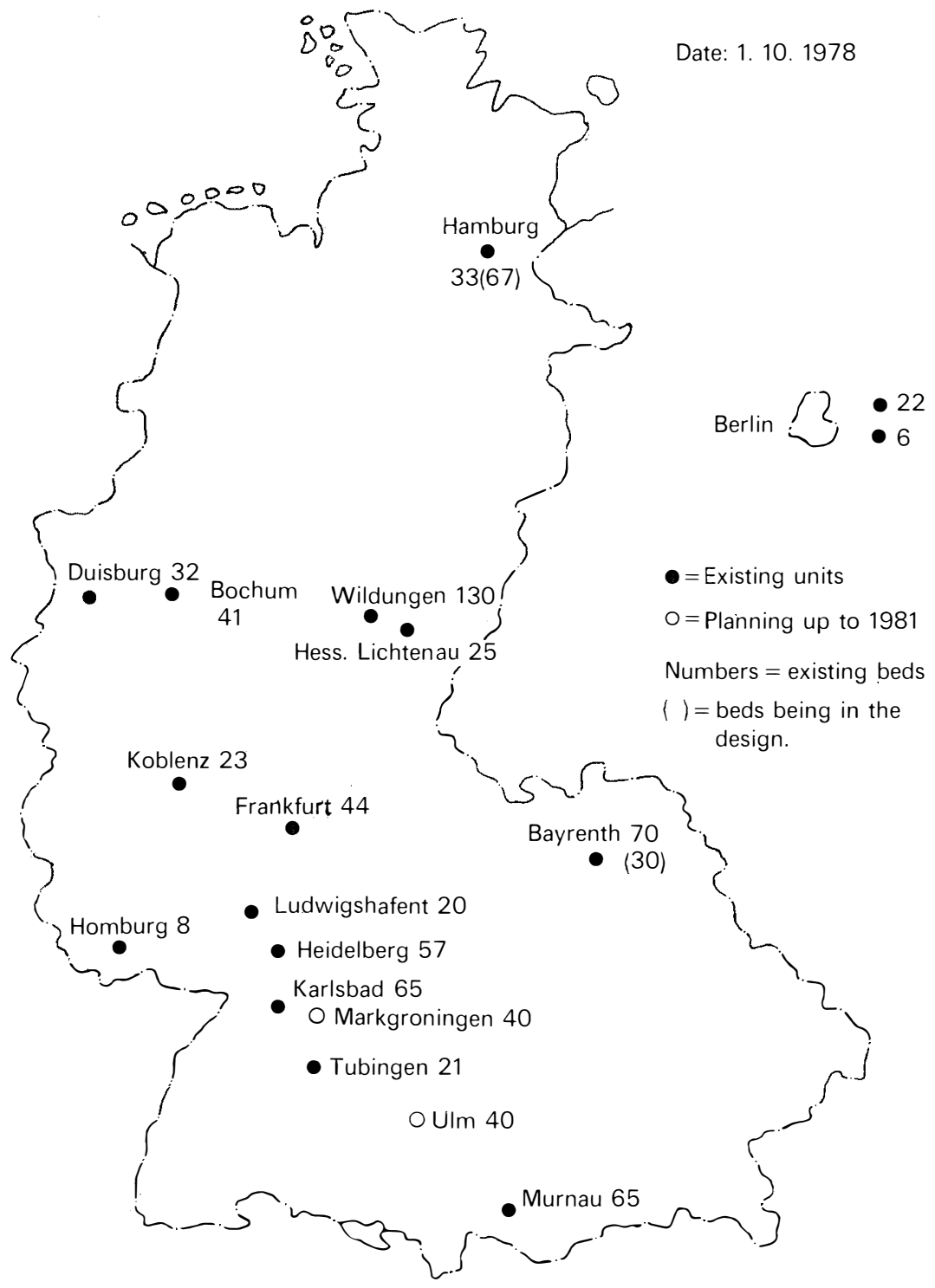

FIG. I

Spinal units for admission of recent cases in the Federal Republic of Germany. I $7 / \mathrm{I}-\mathrm{E}$ 
TABLE I

Addresses of the units in the Federal Republic of Germany

\begin{tabular}{|c|c|c|c|}
\hline Town & Institution & $\begin{array}{l}\text { Medical Director/ } \\
\text { Head of the Unit }\end{array}$ & Tel. no. \\
\hline $\begin{array}{l}\text { Bad Wildungen - } \\
\text { Reinhardshausen }\end{array}$ & $\begin{array}{l}\text { Werner-Wicker-Klinik } \\
\text { 359o Bad Wildungen- } \\
\text { Reinhardshausen }\end{array}$ & Dr Gerner & $05621 / 831$ \\
\hline Bayreuth & $\begin{array}{l}\text { Krankenhaus Hohe Warte } \\
8580 \text { Bayreuth }\end{array}$ & Priv.-Doz. Dr Grüninger & $092 \mathrm{I} / 28 \mathrm{OI}$ \\
\hline Berlin (ZE) & $\begin{array}{l}\text { Krankenhaus Zehlendorf } \\
\text { Reha- und Sonderstation } \\
\text { für Querschnittgelähmte } \\
\text { IO०० Berlin-Zehlendorf }\end{array}$ & $\begin{array}{l}\text { Dr Drossel } \\
\text { Dr Kisten }\end{array}$ & $\circ 30 / 8$ IO 2 I \\
\hline Berlin (UK) & $\begin{array}{l}\text { Orthop. Univ.-Klinik } \\
\text { Oskar-Helene-Heim } \\
\text { Clayallee } 229 \\
\text { I000 Berlin }\end{array}$ & Prof. Dr Friedebold & O 30/8I 30 II \\
\hline Bochum & $\begin{array}{l}\text { Chir. Univ.-Klinik } \\
\text { BG-Krankenanstalten } \\
\text { „Bergmannsheil-Bochum“ } \\
\text { Hunscheidtstraße I } \\
4630 \text { Bochum }\end{array}$ & $\begin{array}{l}\text { Prof. Dr Rehn } \\
\text { Dr Bötel }\end{array}$ & $0234 / 3021$ \\
\hline Duisburg & $\begin{array}{l}\text { BG-Unfallklinik } \\
\text { Großenbaumer Allee } \\
\text { 4IOO Duisburg-Buchholz }\end{array}$ & $\begin{array}{l}\text { Prof. Dr Hierholzer } \\
\text { Dr Turban }\end{array}$ & $0203 / 7688 \mathrm{I}$ \\
\hline Frankfurt/Main & $\begin{array}{l}\text { BG-Unfallklinik } \\
\text { Friedberger Landstr. } 430 \\
6000 \text { Frankfurt/Main }\end{array}$ & $\begin{array}{l}\text { Prof. Dr Contzen } \\
\text { Dr Stock }\end{array}$ & 06 I I/I 50 II \\
\hline Hamburg & $\begin{array}{l}\text { BG-Unfallkrankenhaus } \\
\text { Bergedorfer Straße IO } \\
2050 \text { Hamburg } 80\end{array}$ & $\begin{array}{l}\text { Dr Zimmer } \\
\text { Dr Böttcher }\end{array}$ & O 40/73 9I I I \\
\hline Heidelberg & $\begin{array}{l}\text { Abteilung für die Behandlung und } \\
\text { Rehabilitation Querschnittgelähmter } \\
\text { der Orthop. Univ.-Klinik } \\
\text { Schlierbacher Landstr. 200a } \\
6900 \text { Heidelberg }\end{array}$ & Prof. Dr Paeslack & $0622 I / 806 I$ \\
\hline Hess. Lichtenau & $\begin{array}{l}\text { Orthop. Klinik und } \\
\text { Rehabilitationszentrum } \\
\text { der Diakonie } \\
3436 \text { Hess. Lichtenau }\end{array}$ & $\begin{array}{l}\text { Prof. Dr Langhagel } \\
\text { Fr. Dr Witzenrath }\end{array}$ & $05602 / 202 \mathrm{I}$ \\
\hline Homburg/Saar & $\begin{array}{l}\text { Orthop. Univ.-Klinik } \\
6650 \text { Homburg/Saar }\end{array}$ & Prof. Dr Mittelmeier & O $684 \mathrm{I} / \mathrm{I} 62203$ \\
\hline $\begin{array}{l}\text { Karlsbad- } \\
\text { Langenstein- } \\
\text { bach }\end{array}$ & $\begin{array}{l}\text { Südwestdeutsches Rehabilitations- } \\
\text { krankenhaus } \\
75 \text { I6 Karlsbad I }\end{array}$ & Dr Aalam & $\begin{array}{l}\circ 7202 / 6 \text { I } 8 \text { I } 3 \\
\text { od. } \\
\circ 7202 / 6 \text { I } 8 \text { I } 4\end{array}$ \\
\hline Koblenz & $\begin{array}{l}\text { BG-Sonderstation für Schwerunfall- } \\
\text { verletzte } \\
\text { Ev. Stift St. Martin } \\
\text { Johannes-Müller-Straße } \\
5400 \text { Koblenz }\end{array}$ & $\begin{array}{l}\text { Prof. Dr Dürr } \\
\text { Dr Lang }\end{array}$ & 02 6I/I OO I I \\
\hline Ludwigshafen & $\begin{array}{l}\text { BG-Unfallklinik } \\
\text { Pfennigsweg I } 3 \\
\text { 6700 Ludwigshafen-Oggersheim }\end{array}$ & $\begin{array}{l}\text { Dr Arens } \\
\text { Fr. Dr Haddenbrock }\end{array}$ & $062 \mathrm{I} / 68 \mathrm{I}$ OI \\
\hline Murnau & $\begin{array}{l}\text { BG-Unfallklinik } \\
\text { 8 I Io Murnau/Obb. }\end{array}$ & $\begin{array}{l}\text { Prof. Dr Probst } \\
\text { Dr Ruidisch }\end{array}$ & ० 88 4I/I 9I \\
\hline Tübingen & $\begin{array}{l}\text { BG-Unfallklinik } \\
\text { Rosenauer Weg } \\
\text { 7400 Tübingen }\end{array}$ & $\begin{array}{l}\text { Prof. Dr Weller } \\
\text { Dr Bilow }\end{array}$ & $0707 \mathrm{I} / 606 \mathrm{I}$ \\
\hline
\end{tabular}




\section{Methods}

Recognising this unsatisfactory situation the Central Association of the Industrial Injuries Insurance Association opened on 2 August, 1976 at the Industrial Injuries Insurance Institute for Research in Traumatology at Frankfurt/Main, in close cooperation with Industrial Injuries Insurance Institutes' Accident Hospital at Frankfurt/Main, a Bed Procurement Bureau for Patients with Spinal Cord Lesions (Clearing-Agency). The service is available round the clock for all patients regardless the cause of paralysis and the insurance responsible for him. The clearing-agency is in close cooperation with I6 spinal units (Table I), dealing with spinal cord lesions in the acute stage. It gets information about beds available at these units and any alteration immediately. The above-mentioned list has been published several times. The hospitals recently have been informed directly by a report about the first year of activity of the clearing-agency (Meinecke, 1978). Hospitals admitting a recent case are requested to contact first the centres in the neighbourhood. If they cannot admit the patient the hospital should then contact the clearing-agency. If there are vacancies the appellant will get this information and is asked to discuss all further questions about transport and admission with the spinal unit concerned. If there are no vacancies the appellant is asked to call the units in the neighbourhood again, referring to the negative information given by the clearing-agency. At the moment the procurement is restricted to those patients who are seeking admission to spinal units for the first time since the paralysis has occurred; also who are staying in hospital from the beginning without any interruption, that is recent cases. There is no legal claim for procurement.

\section{Results}

Within 23 months there were I6I demands and Table II shows to which insurance the patients belonged. In 86 cases ( 53 per cent), a bed was found immediately. The inquiries came in mostly within the first 24 hours after the onset of the lesion and procurement was possible usually within the next 24 hours. Inquiries made by the clearing-agency on non-procured patients in the first hospital showed clearly that most of them could be transferred to a specialised service on the same day, or within the following week.

TABLE II

Insurance of the announced cases from 2 August 1976 to 30 June 1978

\begin{tabular}{lccc}
\hline & Announced & Procured & Not procured \\
\hline Industrial injuries insurances & 30 & I6 & I4 \\
Legal sickness insurances & 87 & 45 & 42 \\
Armed forces & 4 & I & - \\
Disabled ex-soldier administration & - & I & I \\
Welfare administration & 2 & I & - \\
Private insurances & I & I & - \\
Other insurances & I & $2 \mathrm{I}$ & I5 \\
Unknown & 36 & 86 & 75 \\
$\quad$ Total & I6I & & \\
\hline
\end{tabular}


It was not advisable to establish waiting lists as this would result in waiting time between the onset of the lesion and the possible procurement for the patient. By that, the complication rate for all patients would increase, whereas the aim of this clearing-agency is to avoid complications as much as possible.

\section{Further Consequences}

Every 6 months all units concerned give a report about their figures of admissions of recent cases within that time. The report's content can be seen in detail in Table III. Some of these results after 23 months of activity are summarised in Tables IV and V. There is a constant ratio of tetraplegics : paraplegics of $40: 60$. The results are based on 500 beds within the units concerned. There was an overall number of admissions of 1296 cases, with an average number of 732 cases/ year. There is no doubt that there is still a great number of unknown cases.

TABLE III

Sheet I: Recent cases

Sender:

Time: from

to

I. Special beds for paralysed patients

2. Admissions of recent cases between and

2.I. of them female

2.2. of them male

2.3. of them children (up to I4 years of age)

2.3.I. of them female

2.3.2. of them male

2.4. of them tetraplegics

2.5. of them paraplegics

2.6. of them without procurement by the clearing-agency

2.7. of them with procurement by the clearing-agency

3.

3.I. Accident at work

3.2. Road accidents (way to and back from work included)

3.3. Sport accidents (diving excluded)

3.4. Diving

3.5. Suicide attempts

3.6. Outside killing attempts

3.7. Diseases

3.8. Congenital deformities

3.9. Other accidents

4. Insurances of the under 2 mentioned patients

4.I. Industrial injuries insurances

4.2. Legal sickness insurances

4.3. $\quad$ Armed forces

4.4. Disabled ex-soldier administration

4.5. Welfare administration

4.6. Private insurances

4.7. Other insurances

4.8. Unknown 


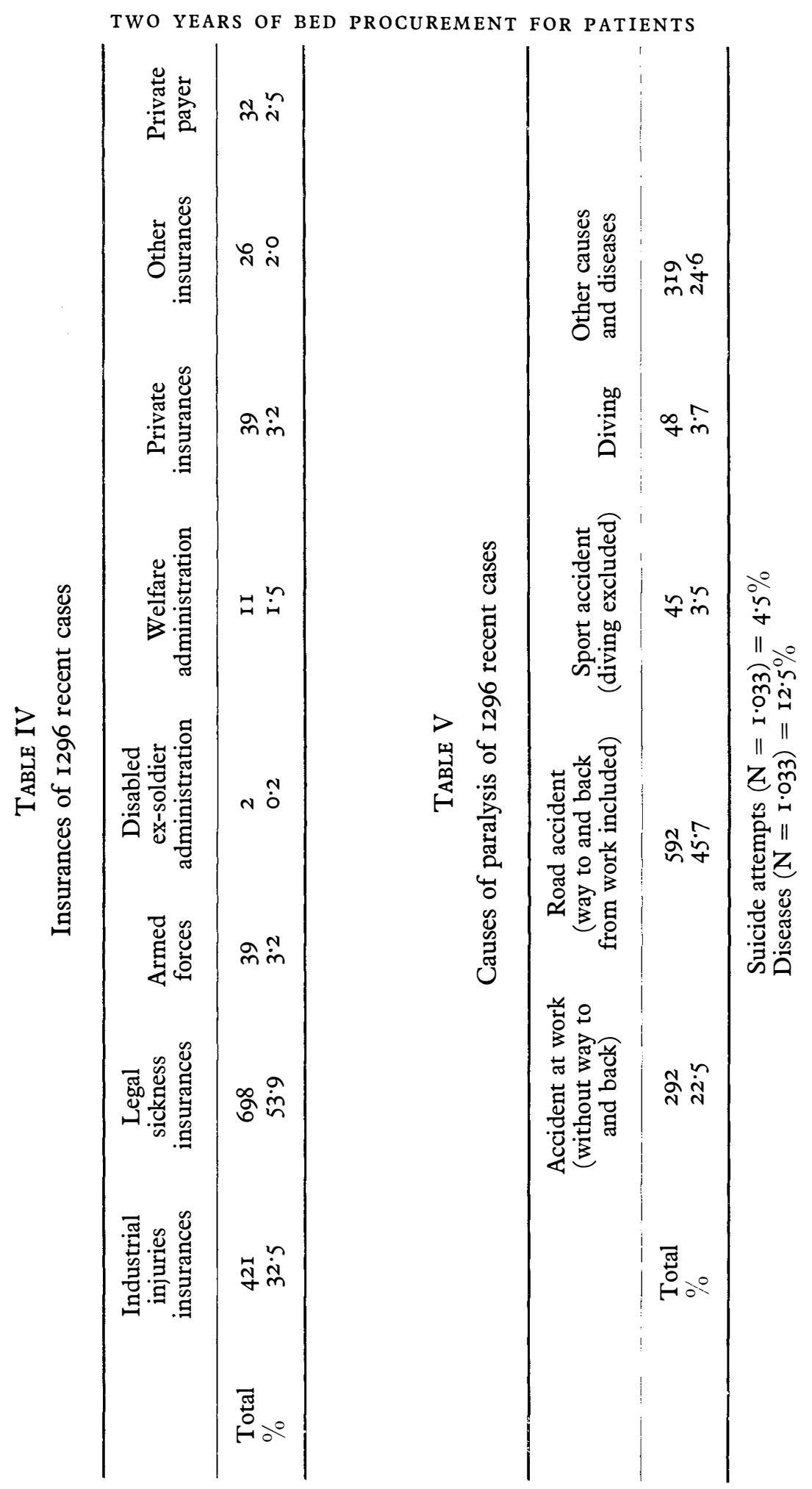


unaccounted for. Six per cent of all admissions were arranged by the clearingagency's procurement.

The heads of the units concerned meet every 6 months regularly in order to discuss problems and experiences. Thus there was set up a special study group in the Federal Republic of Germany and it is also planned to invite German-speaking specialised colleagues from other countries to join those meetings.

In order to obtain rigid figures about the readmissions and the outpatients there have been developed additional sheets meanwhile (Tables VI and VII) and the results will be summarised every 6 months. As this has been done up to now only for a short time it does not seem to be useful yet to publish these figures.

\section{Discussion}

The establishment of this clearing-agency has been proved very satisfactory and it becomes recognised more and more. The support the agency can give is

\section{TABLE VI}

Sheet 2: Readmissions

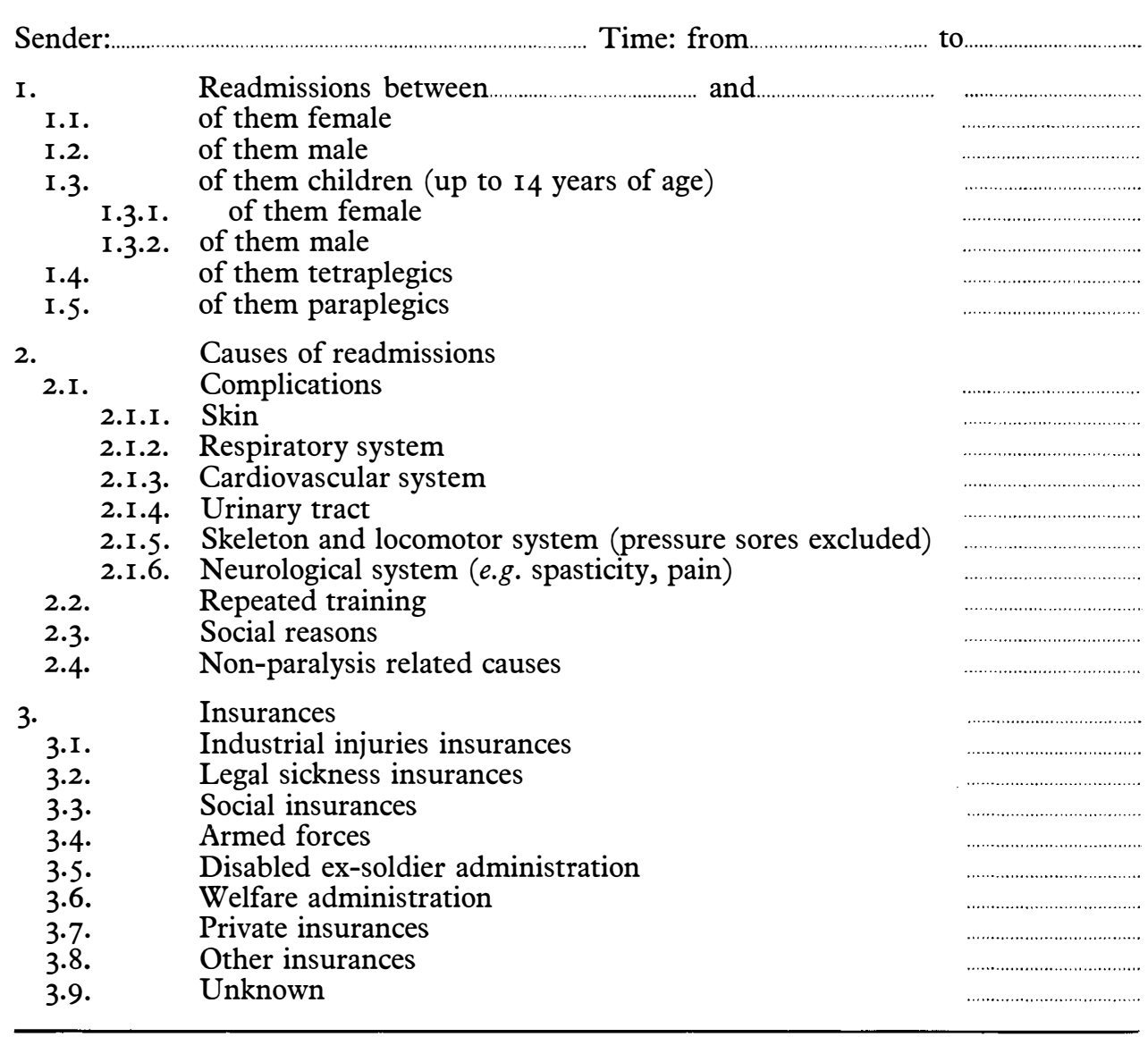


TABLE VII

Sheet 3: Outpatients

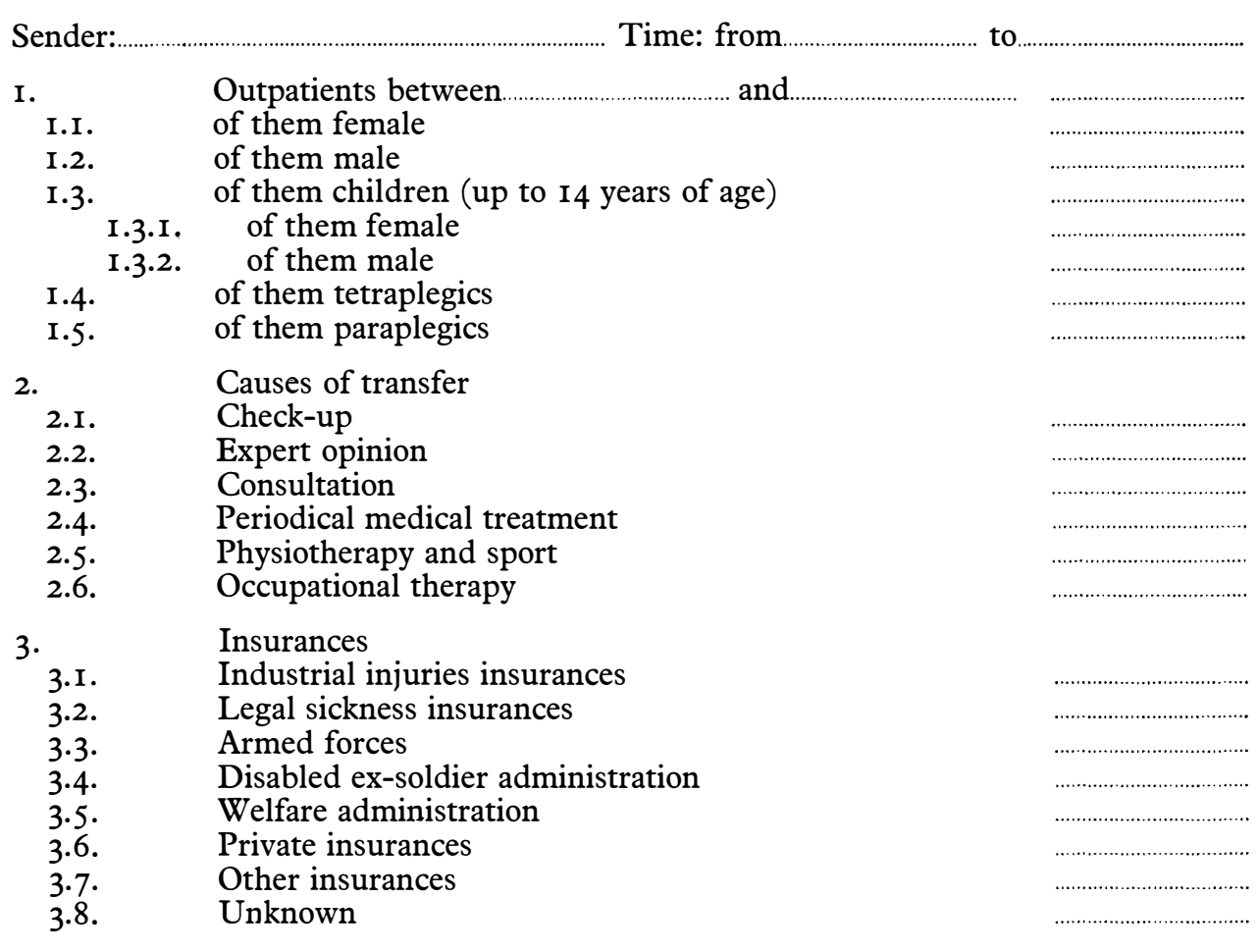

gratefully appreciated by patients, physicians and spinal units. The possibilities will improve when a sufficient number of beds in special units can be provided.

Today there are 662 beds available in the institutions concerned. There are additional facilities in hospitals either to take care of single recent cases or to admit patients for further training when the acute and early stages have passed. That brings the number to a total of 762 beds. Forty-four per cent of all the institutions belong to the Industrial Injuries Insurance Institutes directly, or are getting financial support by them. Up to I98I there is an estimated increase of another I80 beds which would lead to a total of 942 beds, 842 of them in institutions capable of admitting recent cases.

The figures summarised regularly from all the institutions concerned are established and seem to confirm the estimates done in the past, e.g. it can be expected that 1000 new lesions a year will occur in the Federal Republic of Germany, about 15 per cent being of non-traumatic origin. The same result may be expected by collecting the figures of readmissions and outpatients. The great number of unknown patients must be stressed here again but this will decrease within the next few years as the registration of cases is improved.

These figures represent a reliable basis with regard to planning programmes for the future. By that, administrators as well as politicians, are becoming aware more and more of the statistics given by the clearing-agency. There is a steady and 
close cooperation. It is, no doubt, already evident that there does not exist any overcapacity and that there will have to be new units in those parts of Germany where there is still a great lack of spinal centres. That can be seen from Figure $\mathrm{I}$. With an increase of special facilities the aftercare of discharged patients (readmissions for complications, training, check-ups, temporarily interrupted care at home etc). will improve. The smaller units cannot be given up yet.

The special study group discusses medical, social, vocational and medico-legal problems at short intervals. On a comparable basis special questions of research, e.g., conservative or operative treatment of spinal or spinal cord injuries, new methods of urological treatment, can be handled together within a framework of criteria over a longer period of time. Questions coming from outside to this group can be discussed and answered on a broad basis of experience. The regular meetings will benefit the knowledge between all the participants, the understanding with each other and the cooperation. New colleagues entering this group will find advice and help quickly.

\section{Conclusions}

The clearing agency has proved as an efficient method of removing the difficulties from less experienced physicians and from hospitals which are not prepared to undertake the special care for patients with spinal cord lesions. With regard to the existing lack of beds in spinal units, long distances between the patient's home and the place of treatment are still unavoidable. The smaller specialised institutions are still urgently needed. The special study group formed by the clearing-agency offers both an extensive exchange of experiences and firm figures as an effective aid for planning programmes for the future. This will facilitate today's still insufficient facilities for those patients who do not belong to the Industrial Injuries Insurance Institutions. In addition, this working group represents an experienced committee and is available to answer questions arising from the broad plan of the comprehensive treatment of patients suffering from spinal cord lesions according to Sir Ludwig Guttmann.

We are indebted to the Central Association of the Industrial Injuries Insurance Association of the Industrial Injuries Insurance Institutes and its institutions concerned, which took the initiative to set up the clearing-agency and for the great support given to it and to the specialised study group from the beginning. We are grateful to the Industrial Injuries Insurance Institute's Accident Hospital at Frankfurt/Main as well as to all physicians of the spinal institutes concerned for their great assistance and close cooperation. We are thus enabled to dedicate this paper today, as a group, to Sir Ludwig Guttmann on the occasion of his 8oth birthday. We are glad to be able to express our deep gratitude, not only for the great life-work he has done, but also for the interest and the great help he has given during the years to the tetra- and paraplegics in the Federal Republic of Germany and to all those who are engaged in this field in this country in order to improve the prospects of these patients.

\section{SUMMARY}

The total number of beds provided in all specialised centres for the treatment of patients with acute spinal cord lesions in the Federal Republic of Germany is still insufficient. Therefore the attempt to transfer those patients to a centre from 
another hospital immediately after the lesion has occurred is very difficult. In order to assist physicians of the hospitals (where the patient has been first admitted) in the time-consuming task to find a vacancy in a specialised unit, the Central Association of the Industrial Injuries Insurance Association of the Industrial Injuries Insurance Institutes set up a 'Bed Procurement Bureau for Patients with Spinal Injuries' on 2 August, 1976. The heads of the units concerned set up a special study group in close connection with this clearing-agency in order to elaborate reliable data about the present situation of care for recently paralysed people, and to discuss further problems as well as planning programmes. They meet every 6 months. The organisation of the clearing-agency, the experiences gained within the first 23 months of activity since the opening, the spinal units situation at the present time, and their further development are reported.

\section{RÉSUMÉ}

Dans la République Fédérale de l'Allemagne, l'hospitalisation de tous les paraplégiques lésés récemment dans un centre spécialisé cause beaucoup de difficultés, car le nombre des places de traitement disponibles n'y suffit pas.

Pour assister les médecins dans les hôpitaux qui admettent les premiers ces lésés, en leur recherche d'une possibilité d'admission dans un centre spécialisé, la Fédération des Associations professionnelles établit en août 2, I976 un 'Centre communiquant les lits à la disposition des paraplégiques'. Les directeurs des centres y participants se réunirent dans un groupe de coopération, qui discute tous les six mois régulièrement des problèmes et des questions en traitement et établissement de paraplégiques. On rapporte de l'organisation du 'Centre communiquant les lits à la disposition des paraplégiques', des expériences que l'on gagnait pendant les 23 mois depuis sa fondation, de la situation actuelle et du développement futur des centres spécialisés au traitement de lésions médullaires.

\section{ZUSAMMENFASSUNG}

In der Bundesrepublik Deutschland bereitet die sofortige Aufnahme aller frischen Querschnittgelähmten in ein Spezialzentrum große Schwierigkeiten, da die Zahl der zur Verfügung stehenden Behandlungsplätze dort nicht ausreicht. Um Ärzten in den erstaufnehmenden Krankenhäusern bei der zeitraubenden Suche nach einer Aufnahmemöglichkeit in einem Zentrum zu helfen, hat der Hauptverband der gewerblichen Berufsgenossenschaften am 2. August 1976 eine 'Anlaufstelle für die Vermittlung von Betten für Querschnittgelähmte' eingerichtet. Die Leiter der daran beteiligten Zentren haben sich zu einem Arbeitskreis zusammengeschlossen, der realistische Grundlagen über die aktuelle Versorgung Querschnittgelähmter erarbeitet und anstehende Probleme in Abständen von 6 Monaten regelmäßig erörtert. Es wird über die Organisation der Anlaufstelle, die Erfahrungen innerhalb der ersten 23 Monate seit ihrem Bestehen, über den gegenwärtigen Stand und die künftige Entwicklung der Zentren berichtet.

\section{REFERENCES}

ARENs, W. (1958). Gedanken zum Querschnittgelähmten-Problem. H. Unfallheilk. 56, 232-237.

BUNDESÄRZTEKAMMER, Wiss. Beirat (1973). Versorgung von Querschnittgelähmten. Dtsch. Arztebl. 70, 1269-1276, 1347-1 354 .

BÜRKLE DE LA CAMP, H. (1959). Behandlung und Wiedereingliederung Wirbelverletzter. Berufsgenossenschaft, 7, 29I-296.

GuttmanN, L. (I97I). Prinzipien und Methoden in der Behandlung und Rehabilitation von Rückenmarkverletzten. In F. K. Kessel, L. Guttmann, and G. Maurer (eds.) Neuro-Traumatologie, II, 76-I63. Urban und Schwarzenberg, München-Berlin-Wien.

HAUPTVERBAND DER GEWERBLICHEN BERUFSGENOSSENSCHAFTEN (1978). Zur Neuordnung der Behandlungszentren für Querschnittgelähmte in der Bundesrepublik Deutschland mit Planungsrichtwerten für Neubauten. Schriftenreihe Hauptverband der gewerbl. Berufsgenossenschaften e. V., Bonn. 
Leimbach, G. (1964). Das Querschnittsgelähmten-Problem in der Bundesrepublik Deutschland. H. Unfallheilk. 78, 285-292.

Lemberg, K. L. (I96I). Die Rehabilitation Querschnittsgelähmter. Münch. Med. Wschr. I03, 1005 .

LEMBERG, K. L. (I96I). Über die Komplikationen der Querschnittslähmungen. Münch. Med. Wschr. 103, 2213.

Meinecke, F.-W. (1967). The situation of a spinal unit in an accident hospital. Paraplegia, 5, I $47-150$.

MEINECKE, F.-W. (1969). The rehabilitation of paraplegics and tetraplegics in West Germany. Paraplegia, 7, 206-208.

MEINECKE, F.-W. (I970). Behandlungsmöglichkeiten für Querschnittsgelähmte in der Bundesrepublik Deutschland. Dtsch. Arztebl. 67, 413-4I8, 506-5I I.

MeINECKE, F.-W. (I978). Vermittlung von Betten für Querschnittgelähmte. Unfallheilk. 81, 593-600.

PaeslaCK, V. (1968). Querschnittlähmung-Behandlung, Pflege und Rehabilitation. Kohlhammer, Stuttgart, Köln, Berlin, Mainz.

PAESLACK, V. (I97I). Internistische Fragestellungen bei der Rehabilitation Querschnittgelähmter. Internist, 12, 230-232.

PaEslaCK, V. (1978). Internistische Fragestellungen bei der Frühbehandlung des Halsmarkverletzten. H. Unfallheilk. 132, 355-360.

Probst, J. (I972). Behandlung, Rehabilitation und Nachbetreuung Rückenmarkverletzter. Schriftenreihe Unfallmed. Tagg. d. Landesverbände d. gewerblichen Berufsgenossenschaften H. I5, Hauptverband der gewerblichen BGen, Bonn.

Stoephasius, E. (I970). The spinal unit at Murnau (Germany). Paraplegia, 8, I42-I44. 